\title{
Perilaku Perusahaan Multinasional Dan Aggressive Transfer Pricing Practices Terhadap Kepatuhan Pembebanan Biaya Promosi (Studi Kasus Kasus PT MSM)
}

\author{
Supriyadi \\ Sekolah Tinggi Akuntansi Negara (STAN) \\ Email: priesoekarno@gmail.com
}

\section{ARTICLE INFO}

Keywords:

MNEs Behavior, Aggressive Transfer Pricing Practices, Compliance of Promotion Expenses

\section{ABSTRACT}

This research aimed to analyze Multinational Enterprises behavior and aggressive transfer pricing practices that compliance of promotion expenses (Case Study PT MSM). First, to analyze formal compliance of promotion expenses on MNEs. Second, to analyze material compliance of promotion expense on MNEs. Third, to analyze economic benefits for PT MSM and MNEs.

The research approach used is descriptive qualitative with data collection through indepth interviews with informations determinded by Account Representative of the Tax Sercive Office B that handles PT MSM. The research instrument is the data and information collection through interview dan documentation. This reseach is used MNEs theory and compliance theory.

The research results show that: first, promotion expenses on MNEs that Case Study PT MSM reach about Rp 3,2triliun from fiscal year about 2003 until 2016 average 20\% form sales. For formal compliance analysis for promotion expenses for PT MSM is comply with Ministry of Finance Regulation number 02/PMK.03/2010 about promotion expenses with attaching nominative list of promotion expenses. Second, for material compliance analysis of promotion expenses is not directly related for PT MSM, to promote MNEs. Third, promotion expenses that paying PT MSM gives economic benefit for promotion of MNEs. Therefore PT MSM should get renumeration because of its function, assets and risks.

\section{PENDAHULUAN}

Perkembangan globalisasi yang sangat cepat atas teknologi informasi, komunikasi, dan transportasi mendorong perusahaan multinasional untuk melakukan transaksi dengan perusahaan afiliasinya baik di dalam negeri maupun luar negeri. Dari persfektif pemerintah, globalisasi memberikan peluang untuk menarik investasi luar negeri, perdagangan internasional dan lapangan pekerjaan. Dalam presfektif perusahaan multinasional globalisasi akan mengurangi biaya produksi, peningkatan potensi pasar dan laba.

Dalam rangka peningkatan potensi pasar dan laba perusahaan multinasional menggunakan transfer pricing untuk transaksi afiliasinya. Praktik transfer pricing awalnya tidak dimaksudkan untuk melakukan penghindaran pajak, tetapi untuk efisiensi perusahaan dalam rangka mengalokasikan sumber daya. Pada perkembangannya praktik transfer pricing pada perusahaan multinasional ini berkembang menjadi praktik aggressive transfer pricing. Praktik perusahaan multinasional ini termasuk legal, tetapi menggunakan pendekatan yang tidak konsisten dengan kondisi ekonomi untuk meminimalisir kewajiban perpajakan secara keseluruhan dari perusahaan multinasional yang menjadi afiliasinya.

Penulis menggunakan terminologi perusahaan multinasional ini mengacu pada definisi yang diajukan oleh Eden. Perusahaan multinasional terdiri dari satu atau dua perusahaan yang berada di bawah kendali (control) yang sama, dengan menggabungkan sumber daya untuk mencapai tujuan bersama yang unit usahanya terletak di lebih dari satu negara.

Sehubungan dengan penelitian yang dilakukan oleh Eden mengenai keterkaitan antara pemerintah, ketidaksempurnaan pasar dan praktik aggressive transfer pricing di Amerika Serikat terdapat beberapa temuan antara lain: 
1. Praktik aggressive transfer pricing akan dipicu oleh faktor pasar dan pemerintah;

2. Praktik aggressive transfer pricing akan cenderung dilakukan jika pasar tidak memiliki harga referensi;

3. Skala (ukuran) perusahaan multinasional akan berkorelasi positif dengan aggressive transfer pricing. Perusahaan multinasional yang berskala lebih besar akan lebih memiliki kecenderuangan untuk terlibat dalam aggressive transfer pricing;

4. Praktik aggressive transfer pricing akan cenderung dilakukan pada jenis produk yang semakin terdiferinsiasi, sarat dengan teknologi, atau intensif terhadap pengetahuan.

Dalam rangka peningkatan pasar dan laba perusahaan multinasional banyak yang menggunakan strategi promosi. Promosi mempunyai arti aktivitas yang menyampaikan manfaat produk dan membujuk pelanggan membelinya (Kolter dan Amstrong, 1999). Perusahaan yang menjual prioduk yang sama (standardized product) di beberapa pasa cenderung menstandardisasi strategi promosi mereka. Standardisasi berarti menerapkan strategi promosi yang sama di seluruh negara tujuan. Strategi promosi yang bersifat global menyeragamkan pesan yang disampaikan, tetapi beberapa terdapat perubahan sedikit dalam strategi promosinya yang dibuat untuk mematuhi peraturan lokal dan memperoleh merespon konsumen lokal (Kotabe dan Helsen, 2011).

Dalam ketentuan perpajakan biaya promosi dapat digunakan sebagi pengurang dalam penghitungan penghasilan kena pajak dan pajak terhutang Biaya promosi adalah bagian dari biaya penjualan yang dikeluarkan oleh Wajib Pajak dalam rangka memperkenalkan dan/atau mengajurkan pemakaian suatu produk baik langsung maupun tidak langsung untuk mempertahankan dan/atau meningkatkan penjulan. Biaya promosi sebagai biaya yang dapat dikurangkan sesuai Pasal 6 ayat (1) huruf a Undang-undang Pajak Penghasilan.

Ketentuan lebih lanjut terkait pembebanan biaya promosi diatur dalam Peraturan Menteri Keuangan Nomor 02/PMK.03/2010, yang mengatur antara lain:

1. Besarnya biaya promosi yang dapat dikurangkan dari penghasilan bruto merupakan akumulasi dari jumlah:

a. Biaya periklanan di media elektronik, media cetak dan/atau media lainnya;

b. Biaya pameran produk;

c. Biaya perkenalan produk baru; dan/atau

d. Biaya sponsorhip yang berkaitan dengan promosi produk.

2. Tidak termasuk biaya promosi sebagaimana dimaksud dalam Pasal 2 adalah:

a. Pemberian imbalan berupa uang dan/atau fasilitas, dengan nama dan dalam bentuk apapun, kepada pihak lain yang tidak berkaitan dengan penyelenggaraan kegiatan promosi.

b. Biaya promosi untuk mendapatkan, menagih dan memelihara penghasilan yang bukan merupakan obyek pajak dan yang telah dikenai pajak bersifat final.

Pada penelitian sebelumnya peneliti melakukan penelitian terkait pembebanan biaya promosi atas Wajib Pajak Farmasi yang terdaftar di Kantor Pelayanan Pajak Perusahaan Masuk Bursa pada tahun 2013 dengan judul "Implementasi Peraturan Menteri Keuangan Nomor 02/PMK.03/2010 tentang Biaya Promosi yang dapat dikurangkan dari Penghasilan Bruto (Studi Kasus Wajib Pajak Farmasi pada KPP Perusahaan Masuk Bursa)". Dari penelitian tersebut peneliti menemukan data Wajib Pajak Farmasi yang penulis jadikan sebagai objek penelitian, pembebanan biaya promosinya mencapai 32,30\% dari peredaran usaha yang dilaporkan oleh Wajib Pajak. Ketika Wajib Pajak Farmasi dilakukan pemeriksaan oleh Tim Pemeriksa KPP Perusahaan Masuk Bursa diketahui bahwa atas pembebanan biaya promosi tersebut oleh tim pemeriksa tidak sesuai ketentuan sehingga harus dilakukan koreksi mencapai 56,73\% dari jumlah biaya promosi yang dibebankan oleh Wajib Pajak Farmasi karena tidak memenuhi ketentuan Peraturan Menteri Keuangan Nomor 02/PMK.03/2010.

Berdasarkan penelitian di lapangan atas data dan informasi terkait pembebanan biaya promosi dengan mengambil studi kasus PT MSM, peneliti menemukan beberapa hal sebagai berikut:

1. PT MSM membebankan biaya promosi sebesar Rp 3.2 trilyun sejak tahun 2003 sampai dengan 2016 mencapai $20 \%$ dari penjualan.

2. Untuk memenuhi peraturan yang berlaku PT MSM telah melampirkan daftar nominatif biaya promosi sesuai yang disyaratkan dalam ketentuan 02/PMK.03/2010. 
3. Dari penelitian atas rasio-rasio keuangan kunci diperoleh data dan informasi bahwa Net Prorit Margin, Gross Profit Margin, Margin on Total Cost dan CCTOR menunjukkan bahawa pembebanan biaya promosi meningkatkan penjualan tetapi tidak signifikan.

4. Biaya promosi ini dibayarkan tidak memberikan manfaat ekonomi atas perusahaan tersebut, tetapi memberikan manfaat ekonomi pada perusahaan multinasional yang menjadi afiliasinya.

Penelitian ini membahas terkait perilaku perusahaan multinasional dan aggressive transfer pricing practices atas kepatuhan pembebanan biaya promosi dengan studi kasus PT MSM dengan fokus penelitian adalah:

1. Analisis kepatuhan formal atas pembebanan biaya promosi pada PT MSM

2. Analisis kepatuhan material atas pembebanan biaya promosi pada PT MSM

3. Analisis manfaat ekonomi atas pembebanan biaya promosi pada PT MSM dan perusahaan multinasional yang menjadi afiliasinya.

Berdasarkan fokus penelitian tersebut, peneliti tertarik untuk melakukan penelitian atas perilaku perusahaan multinasional dan aggressive transfer pricing practices terhadap kepatuhan pembebanan biaya promosi dengan studi kasus PT MSM.

\section{METODE}

Penelitian ini termasuk jenis penelitain kualitatif. Dalam penelitian ini peneliti menggunakan analisis rasio-rasio keuangan kunci, perhitungan matematis, statistik dan pemanfaatan data dan informasi yang relevan. Peneliti menggunakan penelitian kualitatif ini berdasarkan teori yang ada. Dalam penelitian ini peneliti menggunakan penelitian lapangan (field research).

Penelitian ini bersifat deskriftif yaitu dengan menggambarkan dan mendefinisikan siapa yang terkait, apa yang dilakukan, bagaimana melakukan, dimana melakukan dan mengapa melakukan yang terkait perilaku perusahaan multinasional dan aggressive transfer pricing practices terhadap kepatuhan pembebanan biaya promosi dengan studi kasus PT MSM.

Pemilihan informan dalam penelitian ini berdasarkan asas subjek yang memahami permasalahan, memiliki data dan informasi dan bersedia memberikan informasi lengkap dan akurat. Informan dalam penelitian ini harus memenuhi syarat-syarat tersebut. Informan dalam penelitian ini adalah pegawai dari KPP X dan Analis Pajak Senior di Kantor Pusat Direktorat Jenderal Pajak.

Penelitian kualitatif ini tidak mempermasalahkan jumlah informan, tetapi tergantung dari tepat atau tidaknya pemilihan informan kunci (key person) dan kompleksitas dari fenomena sosial yang diteliti. Informan ditentukan dengan teknik snowball sampling, yaitu proses penentuan informan berdasarkan informan sebelumnya tanpa menentukan jumlahnya secara pasti dengan menggali informasi terkait topik penelitian yang diperlukan. Penelitian informan akan dihentikan setelah informs penelitian dianggap memadai.

\section{HASIL}

Peneliti telah secara khusus melalukan penelitian lapangan selama kurang waktu lebih dari dua belas bulan sejak bulan Maret 2017 sampai dengan Maret 2018. Dalam periode tersebut peneliti melakukan enam langkah analisis data kualitatif. Creswell (2010) menyatakan enam langkah analisis data kualitatif yang perlu dilakukan, yaitu:

1. mengolah dan mempersiapkan data untuk dianalisis;

2. membaca keseluruhan data;

3. menganalisis lebih detail dengan meng-coding data;

4. menerapkan coding untuk mendeskripsikan setting, orang-orang, kategori-kategori dan tema-tema yang dianalisis;

5. membuat deskripsi dan tema-tema untuk disajikan dalam laporan kualitatif;

6. menginterprestasi atau memaknai data.

Peneliti mengumpulkan data dan informasi, mengamati dan mengelola data dan informasi secara cermat, mempelajari profil PT MSM, menguji informasi yang keliru, meminimalisir distorsi informasi yang

Supriyadi (Perilaku Perusahaan Multinasional Dan Aggressive Transfer Pricing...) 
ada. Peneliti meyakini bahwa data dan informasi dalam penelitian lapangan ini telah memenuhi keabsahan data karena telah memenuhi unsur kredibilitas, transferabilitas, dependenabilias dan konfirmabilitas.

Berdasarkan data dan informasi terkait PT MSM yang bersumber antar lain dari Profil PT MSM, data internal dan eksternal KPP X, diperoleh data dan informasi sebagai berikut:

a. Profil PT MSM

PT MSM dimiliki oleh GCH (Belanda) sebesar 99,95\% dan Ibu KLM (Indonesia) sebesar 0,05\%. Berdasarkan database komersial orbis diketahui bahwa ultimate owner PT MSM adalah GCPL (India). GCPL memiliki strategi mengembangkan tradename untuk perusahaan multinasional "Godres" ke pasar internasional. Di pasar Indonesia PT MSM mencantumkan tradename "Godres" pada semua produknya. PT MSM menanggung biaya promosi dan pemasaran yang sangat signifikan untuk pengembangan pasar perusahaan multinasional.

b. Karakteristik PT MSM

Berdasarkan data dan informasi dari informan karakteristik usaha PT MSM adalah Contract manufacturer dengan melakukan fungsi lebih yaitu menanggung biaya promosi dan pemasaran.

c. Profil Kinerja Keuangan (dalam jutaan rupiah)

\begin{tabular}{|l|r|r|r|}
\hline \multicolumn{1}{|c|}{ Keterangan } & \multicolumn{1}{|c|}{$\mathbf{2 0 1 4}$} & \multicolumn{1}{c|}{$\mathbf{2 0 1 5}$} & \multicolumn{1}{c|}{$\mathbf{2 0 1 6}$} \\
\hline Peredaran Usaha & 2.636 .910 & 2.858 .354 & 2.946 .848 \\
\hline Biaya Promosi & $\mathbf{4 8 3 . 8 5 2}$ & $\mathbf{5 5 1 . 1 7 3}$ & $\mathbf{6 3 6 . 1 9 6}$ \\
\hline Biaya Royalti & 184.238 & 201.010 & 207.050 \\
\hline Total HPP dan Biaya Operasional & 2.346 .083 & 2.476 .717 & 2.566 .276 \\
\hline Laba Komersial & 331,133 & 397,046 & 406,065 \\
\hline Laba Fiskal & 377,634 & 403,679 & 392,743 \\
\hline PPh & 94.408 & 100.919 & 98.185 \\
\hline
\end{tabular}

d. Rasio-rasio keuangan

\begin{tabular}{|l|r|r|r|}
\hline \multicolumn{1}{|c|}{ Rasio-rasio Keuangan } & $\mathbf{2 0 1 4}$ & $\mathbf{2 0 1 5}$ & $\mathbf{2 0 1 6}$ \\
\hline Return on Sales (ROS) & $12.55 \%$ & $13.89 \%$ & $13.78 \%$ \\
\hline Margin on Total Cost (MOTC) & $14.11 \%$ & $16.03 \%$ & $13.78 \%$ \\
\hline Corporate Tax To Turn Over Ratio (CCTOR) & $3.57 \%$ & $3.50 \%$ & $3.33 \%$ \\
\hline Biaya Promosi/ Peredaran Usaha & $\mathbf{1 8 . 3 2 \%}$ & $\mathbf{1 9 . 2 8 \%}$ & $\mathbf{2 1 . 5 9 \%}$ \\
\hline Biaya Royalti / Peredaran Usaha & $6.98 \%$ & $7.03 \%$ & $7.03 \%$ \\
\hline
\end{tabular}

\section{Penjelasan:}

- Rasio Return On Sales (ROS) adalah rasio yang membandingkan penghasilan bersih operasional dengan peredaran usaha. Penghasilan bersih operasional merupakan nilai dari laba kotor dikurangi biaya operasional, tidak termasuk pendapatan dan biaya lain-lain. Nilai ROS menunjukkan seberapa besar proporsi penjualan perusahaan masih tersisa setelah digunakan untuk menutup seluruh biaya operasional 
perusahaan. Semakin besar nilai ROS menunjukkan bahwa perusahaan makin efisien dalam memanfaatkan biaya-biaya yang dikeluarkannya untuk menghasilkan penjualan.

- Rasio Margin On Total Cost (MOTC) adalah rasio yang membandingkan penghasilan bersih operasional dengan total biaya. Total biaya terdiri atas Harga Pokok Penjualan dan biaya operasional (tidak termasuk pendapatan dan biaya lain-lain). Semakin besar nilai MOTC menunjukkan bahwa perusahaan makin efisien dalam memanfaatkan biaya-biaya yang dikeluarkannya untuk menghasilkan penjualan.

- Rasio Corporate tax To Turn Over Ratio (CTTOR) adalah rasio yang membandingkan PPh Terutang dengan peredaran usaha. Nilai CTTOR menunjukkan besarnya PPh yang terutang dalam suatu tahun relatif terhadap Penjualan yang dilakukan oleh perusahaan. Semakin besar CTTOR menunjukkan makin besar proporsi hasil penjualan perusahaan yang digunakan untuk membayar Pajak Penghasilan.

- Ratio Biaya Promosi dengan Peredaran Usaha adalah perbandingan biaya promosi yang dibayar oleh PT MSM dibandingkan dengan penjualan.

- Ratio Biaya Royalti dengan Peredaran Usaha adalah perbandingan biaya royalti yang dibayar oleh PT MSM dibandingkan dengan penjualan.

\section{PEMBAHASAN}

Berdasarkan pengumpulan data dan informasi dari Profil PT MSM, data internal dan eksternal peneliti melakukan analisis prilaku perusahaan multinasional dan aggressive transfer pricing practices terkait kepatuhan pembebanan biaya promosi tersebut dengan melakukan analisis kepatuhan formal, material dan uji eksistensi, manfaat atas atas pembebanan biaya promosi.

Untuk membahas perilaku perusahaan multinasional dalam hal ini PT MSM, peneliti menggunakan teori perusahaan multinasional. Dalam hal ini, peneliti menggunakan teori internalisasi untuk menjelaskan perilaku perusahaan multinasional. Teori internalisasi ini dilatari upaya pengorganisasian atas saling ketergantungan antarpihak, yang seluruh pihak tersebut mendapatkan suatu rent dengan mengumpulkan secara kolektif berbagai kapabilitas atau kemampuan, baik kemampuan yang sama atau berbeda.

Ketika pasar berada dalam kondisi yang tidak sempurna, ekspansi perusahaan melintasi batas-batas negara akan menjadi lebih efisien apabila terdapat internalisasi biaya yang tidak dapat dikendalikan sepenuhnya oleh perusahaan multinasional tersebut. PT MSM menggunakan strategi biaya internalisasi melalui pembebanan biaya promosi untuk meningkatkan efisiensi dan peningkatan pangsa pasar perusahaan multinasional. Hal ini dikuatkan oleh pendapat Coase bahwa transaksi internal dengan harga yang ditetapkan secara internal dapat menciptkan efisiensi (mengurangi biaya transakasi).

Pembebanan biaya promosi yang ditanggung oleh PT MSM sejak tahun 2003 sampai dengan 2016 sebesar Rp 3,2trilyun merupakan strategi internalisasi untuk meningkatkan efisiensi dan pangsa pasar perusahaan multinasional. Dari data rasio keuangan terlihat bahwa PT MSM dibebani biaya promosi untuk peningkatan efisiensi perusahaan multinasional setiap tahun mengalami peningkatan mulai tahun 2014 sampai 2016 dengan perincian sebesar 18,32\%, 19,28\% dan 21,59\%.

Selanjutnya kajian terkait perususahaan multinasional yang beroperasi di Indonesia menggeser labanya ke negara lain yang tarif pajaknya lebih rendah. Hal ini sesuai dengan disertasi Andy W. Wardhana terkait Empirical Evidencae: MNEs Shift Profit from Indonesia to other Tax Jurisdictions. Pendapat ini didukung oleh beberapa kajian empiris baru-baru ini antara lain: Kristiaji (2015), Purba dan Tran (2016) dan Purba dan Tran (2018). Tiga hasil kajian tersebut menghasilkan bahwa perusahaan multinasional di Indonesia melakukan praktik profit shifting.

Dari tiga kajian di atas menjadi bukti bahwa perusahaan multinasional melakukan praktik profit shifting atas labanya di Indonesia ke negara lain yang tarif pajaknya lebih rendah melalui aggressive transfer pricing practices. Kajian Kristiaji (2015) memberikan kontribusi atas penelitiannya bahwa adanya faktor Base Erosion and Profit Shifting (BEPS) di negara-negara berkembang termasuk di Indonesia. Dua kajian dari Purba dan Tran $(2016,2018)$ menjadi bukti empiris adanya tax base erosion and profit shifting di Indonesia. 
Berdasarkan data dan informasi PT MSM melakukan pembayaran royalti ke luar negeri atas trade name "Godres" ke perusahaan multinasional yang merupakan afiliasinya. Pembayaran ini merupakan bentuk profit shifting ke luar negeri. PT MSM juga melakukan fungsi pemasaran dengan menanggung biaya promosi yang setiap tahunnya mengalami peningkatan.

Barry Larking dalam Gunadi (2016) menyatakan bahwa kepatuhan pajak (tax compliance) sebagai prosedur dan administratif yang harus dilakukan untuk memenuhi kewajiban perpajakan sesuai ketentuan. Sedangkan Benno Togler menyatakan bahwa secara moral kepatuhan pajak menunjukkan struktur kemauan sukarela pelaporan basis pajak dan Leon Yudkin menyebut bahwa secara hukum kepatuhan merupakan kemauan (willful) dengan tujuan sepenuhnya (purposfull) mematuhi kewajiban menyampaikan SPT, membayar dan melaksanakan tindakan terntenu sesuai ketentuan pajak.

Secara administratif berdasarkan Undang-undang Ketentuan Umum dan Tata Cara Perapajakan Nomor 6 Tahun 1983 sebagaimana diubah terakhir dengan Undang-undang Nomor 16 Tahun 2009, Wajib Pajak dianggap memenuhi kewajiban perpajakan jika menyampaikan SPT dengan isi data dan fakta yang relevan, akurat, benar sesuai keadaan sebenarnya, lengkap dan jelas.

Dari beberapa teori kepatuhan di atas, Wajib Pajak yang patuh adalah Wajib Pajak yang taat dan memenuhi serta melaksanakan kewajiban perpajakan sesuai dengan peraturan perundang-undangan perpajakan. Kepatuhan perpajakan dibagi menjadi dua kelompok, yaitu:

a. Analisis Kepatuhan Perpajakan Formal

Kepatuhan perpajakan formal di sini PT MSM telah mendaftarkan diri untuk mendapatkan NPWP dan NPPKP. Kemudian Wajib Pajak telah menyetor dan melaporkan SPT Tahunan PPh Badan sesuai dengan ketentuan yang berlaku. Sedangkan terkait kepatuhan formal atas pembebanan biaya promosi PT MSM telah melampirkan daftar nominatif biaya promosi sesuai PMK-02 Tahun 2010.

b. Analisis Kepatuhan Perpajakan Material

Kepatuhan perpajakan material ini merupakan ketaatan Wajib Pajak dalam memenuhi ketentuan material perpajakan. Ketentuan material ini terdiri dari: benar dalam menghitung pajak terutang, benar dalam memperhitungkan pajak terutang dan benar dalam memotong atau memungut pajak sesuai peraturan perpajakan.

Untuk kepatuhan perpajakan material PT MSM telah memenuhi menghitung, memperhitungkan dan memotong atau memungut pajak sesuai dengan ketentuan antara lain Pasal 6 Undang-undang Pajak Penghasilan dan Peraturan Menteri Keuangan Nomor 02 Tahun 2010 tentang biaya promosi.

Peneliti merekomendasikan untuk menganalisis kepatuhan pajak material perlu dilakukan analisis manfaat ekonomi untuk memperoleh kebenaran material atau substansi dari pembebana biaya promosi tersebut. Hal ini diperlukan karena dari informasi yang diperoleh pembebanan biaya promosi tersebut tidak hanya untuk kepentingan peningkatan pasar PT MSM, tetapi untuk peningkatan perusahaan multinasional yang menjadi afiliasinya.

\section{c. Manfaat Ekonomi atas Biaya Promosi}

Untuk menganalisis kepatuhan perpajakan material ini peneliti melakukan analisis manfaat ekonomi yang diterima oleh Wajib Pajak atas pembebanan biaya promosi yang dikeluarkan oleh PT MSM selama tahun 2003 sampai dengan 2016, diperoleh data sebagai berikut: 


\begin{tabular}{|r|r|r|r|r|r|r|}
\hline No & Tahun & r.Promosi \& Pemasara & \multicolumn{1}{c|}{ SALES } & $\%$ & $\begin{array}{c}\% \\
\text { peningkatan } \\
\text { b.promosi }\end{array}$ & $\begin{array}{c}\% \\
\text { peningkatan } \\
\text { Sales }\end{array}$ \\
\hline 1 & 2003 & $9,259,622,261$ & $166,140,422,620$ & $5.57 \%$ & & \\
\hline 2 & 2004 & $19,153,946,485$ & $254,081,672,026$ & $7.54 \%$ & $106.9 \%$ & $52.93 \%$ \\
\hline 3 & 2005 & $19,439,296,113$ & $327,251,099,291$ & $5.94 \%$ & $1.5 \%$ & $28.80 \%$ \\
\hline 4 & 2006 & $40,394,034,211$ & $290,191,809,246$ & $13.92 \%$ & $107.8 \%$ & $-11.32 \%$ \\
\hline 5 & 2007 & $50,755,927,702$ & $408,902,195,511$ & $12.41 \%$ & $25.7 \%$ & $40.91 \%$ \\
\hline 6 & 2008 & $58,487,601,512$ & $568,830,260,746$ & $10.28 \%$ & $15.2 \%$ & $39.11 \%$ \\
\hline 7 & 2009 & $68,132,837,536$ & $792,836,009,199$ & $8.59 \%$ & $16.5 \%$ & $39,38 \%$ \\
\hline 8 & 2010 & $174,856,511,215$ & $1,006,124,895,481$ & $17.38 \%$ & $156.6 \%$ & $26,90 \%$ \\
\hline 9 & 2011 & $308,186,550,011$ & $1,430,152,685,630$ & $21.55 \%$ & $76,3 \%$ & $42.14 \%$ \\
\hline 10 & 2012 & $359,484,600,463$ & $1,908,268,906,461$ & $18.84 \%$ & $16.6 \%$ & $33,43 \%$ \\
\hline 11 & 2013 & $430,717,533,360$ & $2,124,279,096,770$ & $20.28 \%$ & $19.8 \%$ & $11.32 \%$ \\
\hline 12 & 2014 & $483,852,135,294$ & $2,636,910,753,892$ & $18.35 \%$ & $12.3 \%$ & $24,13 \%$ \\
\hline 13 & 2015 & $551,173,088,849$ & $2,858,354,691,098$ & $19.28 \%$ & $13,9 \%$ & $8.40 \%$ \\
\hline 14 & 2016 & $636,196,071,309$ & $2,946,848,974,251$ & $21.59 \%$ & $15.4 \%$ & $3.10 \%$ \\
\hline
\end{tabular}

Dari data tersebut diketahui bahwa biaya promosi dan pemasaran yang dibebankan oleh PT MSM mencapai Rp 3,2 Trilyun. Biaya promosi tersebut dikeluarkan untuk membayara biaya iklan di TV/media lain. Dari analisis biaya promosi dibandingkan penjualan dari tahun 2003 sampai dengan 2016 diketahui bahwa atas pembebanan biaya promosi tersebut tidak memberikan manfaat ekonomi yang signifikan yang tercermin pada tidak terdapat peningkatan penjualan. Pada tahun pajak 2015 dan 2016 biaya promosi dan pemasaran mengalami peningkatan, tetapi penjualan PT MSM mengalami penurunan.

Selain PT MSM membayar biaya promosi juga membayar royalti atas merk yang dimiliki oleh perusahaan multinasional yang merupakan afiliasinya. PT MSM membayar royalti atas nama grup "godres" yang wajib dicantumkan ke setiap produknya di Indoneisa.

Berdasarkan ketentuan PMK 02 tentang biaya promosi lebih diterapkan untuk memenuhi kepatuhan formalnya saja, material dan substansinya banyak yang belum dilakukan penelitian atau pemeriksaan lebih lanjut.

Dari penelitian tersbut dapat disimpulkan bahwa PT MSM mempunyai karakterisik usaha contract manufacturer dan marketing service provider. Untuk karakteristik usaha contract manufacture, PT MSM melakukan fungsi industri penuh di Indonesia tetapi harus membayar royalty ke pemilik merk produk, nama grup dan know how ke perusahaan afiliasnya di luar negeri. Sedangkan untuk karakteristik usaha marketing service provider, PT MSM mempunyai fungsi tambahan berupa pengembangan pemasaran merk di Indonesia.

Berdasarkan OECD Transfer Pricing Guidelines for Multinational Enterprises and Tax Administrations Article 6.76 dinyatakan bahwa:

Par. 6.75 The principles set out in this Section B must be applied in a variety of situations involving the development, enhancement, maintenance, protection, and exploitation of intangibles. A key consideration in each case is that associated enterprises that contribute to the development, enhancement, maintenance, protection, or exploitation of intangibles legally owned by another member of the group must receive arm's length compensation for the functions they perform, the risks they assume, and the assets they use. In evaluating whether associated enterprises that perform functions or assume risks related to the development, enhancement, maintenance, protection, and exploitation of intangibles have been compensated on an arm's length basis, it is necessary to consider (i) the level and nature of the activity undertaken; and (ii) the amount and form of compensation paid. In assessing whether the compensation provided in the controlled transaction is consistent with the arm's length principle, reference should be made to the level and nature of activity of comparable uncontrolled entities performing similar functions, the compensation received by comparable uncontrolled entities performing similar functions, and the anticipated creation of intangible value by comparable uncontrolled entities performing similar functions. This section describes the application of these principles in commonly occurring fact patterns. 
Atas pembebanan biaya promosi yang dilakukan PT MSM merupakan fungsi tambahan, yaitu melakukan fungsi enhancement dan maintenance merk "Godres" di Indonesia yang manfaat ekonominya adalah untuk kepentingan perusahaan multinasional yang menjadi afiliasinya. Oleh karena fungsi tambahan yang dilakukan oleh PT MSM tersebut perlu diberikan renumerasi atas biaya promosi. Atas pembebanan biaya promosi dan biaya royalti yang dilakukan oleh PT MSM perlu dilakukan analisis risiko transfer pricing karena Wajib Pajak melakukan transaksi afiliasi pada pihak-pihak yang mempunyai hubungan istimewa.

\section{SIMPULAN DAN SARAN}

Berdasarkan pembahasan sebelumnya peneliti menarik beberapa kesimpulan sebagai berikut:

1. Perilaku perusahaan multinasional berorientasi global melakukan praktik aggresif transfer pricing sebagai instrument untuk efisiensi, memaksimalkan laba secar global dan meminimalkan risiko bisnis.

2. Pembebanan biaya promosi yang terkait perusahaan multinasional perlu dilakukan pengawasan dan pemeriksaan lebih mendalam untuk menguji kepatuhan formal, material dan manfaat ekonominya.

3. Analisis biaya promosi dibandingkan dengan penjualan untuk beberapa periode tertentu dapat digunakan sebagai alat pengujian adanya manfaat ekonomi atau tidak. berikut:

Berdasarkan kesimpulan yang dikemukan di atas, penulis memberikan beberapa saran sebagai

1. Bagi Direktorat Jenderal Pajak, perlu meningkatkan. pengawasan dan pemeriksaan terkait pembebanan biaya promosi pada perusahaan multinasional untuk meningkatkan kepatuhan pajak;

2. Bagi Kementerian Keuangan, perlu mengkaji dan melakukan perubahan terhadap Peraturan Menteri Keuangan Nomor 02/PMK.03/2010 dengan memperhatikan pembebanan biaya promosi untuk perusahaan multinasional;

3. Bagi Wajib Pajak, perlu meningkatkan kepatuhan kewajiban perpajakannya baik formal dan material sesuai dengan ketentuan perpajakan.

\section{DAFTAR PUSTAKA}

Badan Kebijakan Fiskal, 2016, Menggali Potensi Penerimaan Negara di Tengah Lesunya Ekonomi Global. PT Nagakusuma Media Kreatif

Butarbutar, Russel, 2016, Hukum Pajak Indonesia dan Internasional, Gramata Publishing. Bekasi

Darussalam, Danny Septriadi dan B. Bawono Kristiaji, Transfer Pricing Ide, Strategi, dan Panduan Praktis dalam Perspektif Pajak Internasional. Danny Darussalam Tax Center.

Gunadi, 2017, Panduan Komprehensif Ketentuan Umum Perpajakan (KUP), Jakarta, Penerbit Bee Media Indonesia.

Joel Cooper, Randall Fox, Jan Loprick and Komal Mohindra. 2016. Transfer Pricing and Developing Econimics. World Bank Group.

Kurniawan, Anang Mury, 2014, Transfer Pricing untuk Kepentingan Pajak, Penerbit Andi Yogyakarta.

OECD Transfer Pricing Guidelines for Multinational Enterprises and Tax Administrations. July 2017. OECD

Pohan, Chairil Anwar, 2018, Pedoman Pajak Internasional, Edisi Pertama, Percetakan PT Gramedia, Jakarta.

Wardhana, Andy Wisnu, 2019, A Policy Proposal To Address Tax Base Erosion Caused by Transfer Pricing in Indonesia. Queensland University of Technology.

Undang-undang Ketentuan Umum dan Tata Cara Perapajakan. 2009. Direktorat Jenderal Pajak.

Undang-undang Pajak Penghasilan. 2009. Direktorat Jenderal Pajak.

Supriyadi (Perilaku Perusahaan Multinasional Dan Aggressive Transfer Pricing...) 